[Regular Paper]

\title{
Prediction of Differential Pressure across Tarmat under Water Injection in Reservoir with Two Parallel Faults
}

\author{
Mohammed El-Sayed Osman \\ Chemical \& Petroleum Eng. Dept., University of United Arab Emirates, \\ P.O. Box 17555, Al-Ain, Abu Dhabi, U.A.E.
}

(Received December 7, 1992)

\begin{abstract}
Tarmat problems, which are present in many oil reservoirs, were investigated in a series of studies. This study investigates the case where an injector near two parallel faults is used and arrived at a technique that can be used, both analytically and graphically, to predict differential pressure across the tarmat anywhere in the reservoir. It was found that, during initial period of water injection, the dimensionless pressure across the tarmat is mainly controlled by the coordinates of both the injector and the observation point (location of interest). The presence of the two parallel faults becomes the major factor at a later period. The technique presented in this paper is general and can be applied to any reservoir having three sealing barriers, two of which are parallel and perpendicular to the third one. Also, a set of equations is presented to predict the response time at any observation well in the reservoir.
\end{abstract}

\section{Introduction}

Many oil reservois are characterized by presence of tarmat (heavy oil). Tarmat is present at the oil water interface forming sealing barriers which isolate these reservoirs from their aquifers. Several geochemical studies ${ }^{1,2)}$ indicate that tarmats formed as a result of one or more of the following mechanisms: (1) gravitational segregation that caused the hydrocarbon fractions to stratify with the lighter petroleum at the top of the reservoir and the heavier at the base; (2) natural deasphalting where natural, buoyant gases from the source rock entered the pool and rose through the hydrocarbon column, and (3) water washing, the movement of undersaturated water that removed a portion of light hydrocarbons, leaving asphaltic fractions at the base of oil accumulation.

Tarmats are present in South Iraq and in Kuwait ${ }^{3), 4)}$. The thickness of tarmat in Eid ElShergi field in Qatar is more than $250 \mathrm{ft}(76 \mathrm{~m})$. Also, Dukhan, Maydan, Bulhamine and Mehzan oil fields in Qatar are characterized by presence of tarmat. Tarmats are reported in Manifa, Ghattar and Khursaniya of Saudi Arabia and Sarir oil field of Libya ${ }^{4}$. Bashbush et al. ${ }^{5)}$ discussed the performance of water flooding El Bundug field located in both Abu Dhabi and Qatar states. Geologic and reservoir studies of the field indicated that tarmat acts as a partial barrier to fluid move- ment. Shamsaldeen and Farouq Ali6) studied the effect of steam and solvents on tarmat displacement. They also studied the performance of waterflooding tarmats. They concluded that interaction between the aquifer and the oil zone increases oil recovery. Once interaction is attained, an internal water flood can be very effective. Al-Kaabi et al. ${ }^{7)}$ used a laboratory setup to simulate a fraction of a tarmat reservoir with a well producing from the center. They concluded that presence of barriers decreases the oil recovery from oil reservoirs characterized by presence of tarmat.

A comparative analysis was made by Tripathy ${ }^{8)}$. Depending on viscosity of tarmat, he simulated the tarmat either as a heavy oil or very low permeability matrix forming a part of the aquifer. Tripathy concluded that a rigorous characterization of a tar zone in a model is not possible. However, one of the two concepts can be adopted to a field situation.

Field experience shows that some of these tarmats are mobile under moderate differential pressure across them, while other tarmats are immobile. The differential pressure across tarmats can be caused by oil production from the reservoir and water injection below tarmat. Tarmat breakdown under water injection would serve two purposes. One would be to recover some of tarmat (heavy oil). The other is to increase interaction between the reservoir and it's 
aquifer and thus use the potential energy in producing the oil from the reservoirs. A technique should be available to predict how long water should be injected at certain rate before breaking tarmat at a certain location in the reservoir. Then the injector should be relocated to above the tarmat. The required duration of water injection below and above tarmat should be known for both reservoir management and production operation purposes. The behaviour of tarmat under water injection was treated in several studies. Tarmat behaviour under water injection by an injector away from faults was presented in the first study3), the case of water injection under tarmat by an injector near a single fault was treated in the second study ${ }^{9)}$ and the third study ${ }^{10)}$ treated the case of tarmat behaviour under water injection by an injector located near two interesecting faults.

In this study the effect of presence of two parallel faults nearby water injector on tarmat behaviour is investigated. Design charts, plotted as the dimensionless differential pressure across the tarmat versus dimensionless injection time, can be used to graphically predict the tarmat behaviour anywhere in the reservoir. The application of such charts is illustrated using data of Minagish Oolite reservoir in Kuwait, which is characterized by tarmat presence at oil water contact.

\section{Model Description}

1) The tarmat present at the oil water interface is considered as a sealing barrier between the reservoir and it's aquifer until it breaks down.

2) Differential pressure across tarmat at start of water injection is neglected. Thus conservative predictions are obtained.

3) The two parallel faults are perpendicular to the plane of tarmat.

4) The reservoir and its aquifer behave as an infinite acting reservoir.

The effect of the two faults is simulated by a system of infinite image wells. Figure 1 shows the real system; real well, M (injector), two parallel faults, tarmat planes and an observation point $\mathrm{N}$ and one image well I as an example. The abscisa in Fig. 1 passes through the real well $\mathrm{M}$ (injector), and the ordinate $Y_{\mathrm{D}}$ coinsides with fault No. 1 . Fault No. 2 is parallel to fault No. 1 and separated by a distance which is equal to $w$. Normalizing all distances with respect to $w$, the dimensionless width between the two faults is 1 . Also, $L_{1 \mathrm{D}}$ and $L_{2 \mathrm{D}}$ the dimensionless distances between the observation well (N) and both injector $(\mathrm{M})$ and the image well (I) respectively, the following coordinates are defined as follows:

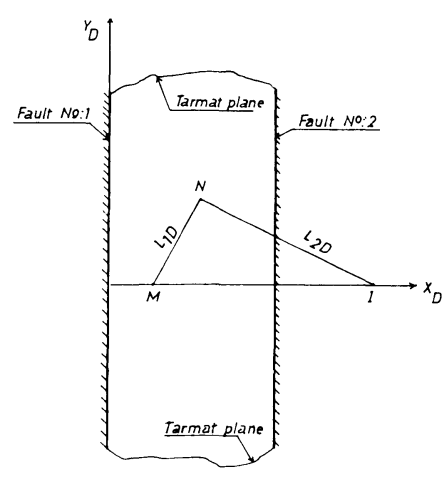

Fig. 1 An injector Located between Two Parallel Faults

The real Well $(\mathrm{M})$ :

$$
\left(X_{\mathrm{DM}}, O\right), \quad O<X_{\mathrm{DM}}<1
$$

The observation point $(\mathrm{N})$ :

$$
\left(X_{\mathrm{DN}}, Y_{\mathrm{DN}}\right), \quad O<X_{\mathrm{DN}}<1 \text { and }-\infty<Y_{\mathrm{DN}}<\infty
$$

The image well (I):

The pressure behaviour of an injector located between the two parallel faults is simulated by a series of infinite image wells. The coordinates of the image wells are defined as :

$$
\left[\left(2 m \pm X_{\mathrm{DM}}\right), o\right], \text { where } m=0, \pm 1, \pm 2, \ldots, \pm \infty
$$

Assuming that the injector is located just below the tarmat, the presence of tarmat doubles the effect of the injector and it's infinite image wells.

The effect of oil production on differential pressure on tarmat is neglected, as was concluded from a previous study3). However, an engineer may take such effect into account when estimating the required differential pressure $\left(\Delta P_{b}\right)$ to break the tarmat. The solution of the diffusivity equation is used to calculate the dimensionless pressure at the tarmat caused by water injection from an injector near the two faults as:

$$
P_{\mathrm{D}}=k_{\mathrm{w}} h(\Delta P) / 141.2 q_{\mathrm{w}} \mu_{\mathrm{w}} \beta_{\mathrm{w}}
$$

thus the dimensionless pressure $\left(P_{\mathrm{D}}\right)$ across the tarmat at point $\mathrm{N}$ (as shown in Fig. $\mathbf{l}$ ) attributed to water injection into a well located at $X_{\mathrm{DM}}$ from faults No. 1 and $\left(1-X_{\mathrm{DM}}\right)$ from fault No. 2 is given as:

$$
P_{\mathrm{D}}=\left[E i\left(-L^{2}{ }_{1 \mathrm{D}} / 4 t_{\mathrm{DW}}\right)+\sum_{j=1}^{\infty} E i\left(-L^{2}{ }_{2 \mathrm{D} j} / 4 t_{\mathrm{Dw}}\right)\right]
$$$$
\text { where: } \quad t_{\mathrm{DW}}=\left(0.0002637 k_{\mathrm{w}}\right) t /\left(\phi c_{\mathrm{t}} \mu_{\mathrm{w}} w^{2}\right)
$$ 


$$
L_{1 \mathrm{D}}=\sqrt{\left(X_{\mathrm{DN}}-X_{\mathrm{DM}}\right)^{2}+Y^{2} \mathrm{DN}}
$$

and

$$
L_{2 \mathrm{D}}=\sqrt{\left(X_{\mathrm{DN}}-X_{\mathrm{D} 1}\right)^{2}+Y^{2} \mathrm{DN}}
$$

\section{Discussion}

Eq. (2) to (5) were used in this study to calculate dimensionless pressure attributed to water injection by an injector nearby two parallel faults.

Figure 2 presents the results of dimensionless pressure versus the injector location $\left(X_{\mathrm{DM}}\right)$ for different dimensionless times. The figure shows that the injector location has negligible effect on the dimensionless pressure at dimensionless times greater than 0.2. Figure 3 presents the results of dimensionless pressure versus the location of

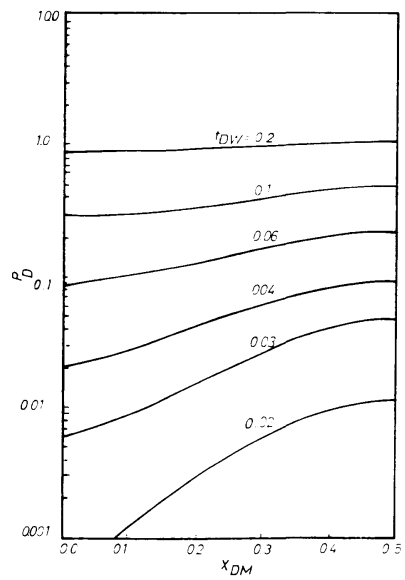

Fig. 2 Relationship between Dimensionless Differential Pressure and the Injector Location for $X_{\mathrm{DN}}=Y_{\mathrm{DN}}=0.5$

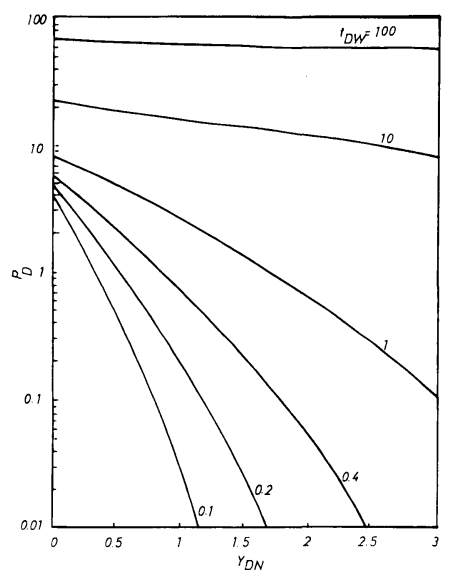

Fig. 3 Relationship between Dimensionless Differential Pressure and Observation Point Location for $X_{\mathrm{DN}}=Y_{\mathrm{DN}}=0.5$ observation point $\left(Y_{\mathrm{DN}}\right)$. The figure shows that the location of observation well has negligible effect at dimensionless times greater than 100 . It is clear from the figure that the dimensionless pressure at any point $(\mathbf{N})$ is greatly affected, during early period of water injection, by it's distance $\left(Y_{\mathrm{DN}}\right)$ from the injector. Such effect becomes minor during later period of water injection. This can be understood when it is kept in mind that the presence of the two parallel faults becomes the controlling factor in the later period of water injection.

Figure 4 presents the relationship of dimensionless pressure versus dimensionless time $t_{\mathrm{DW}}$ for different locations (coordinates) of observation point.

The calculations were extended to different values of real (injector) well and observation point coordinates. The results are presented in Figs. 4 to 11 each of which represents a family of curves of dimensionless pressure versus dimensionless injection time. The main advantage of the charts presented in Figs. 4 to 11 is that they could be used with variable injection rates.

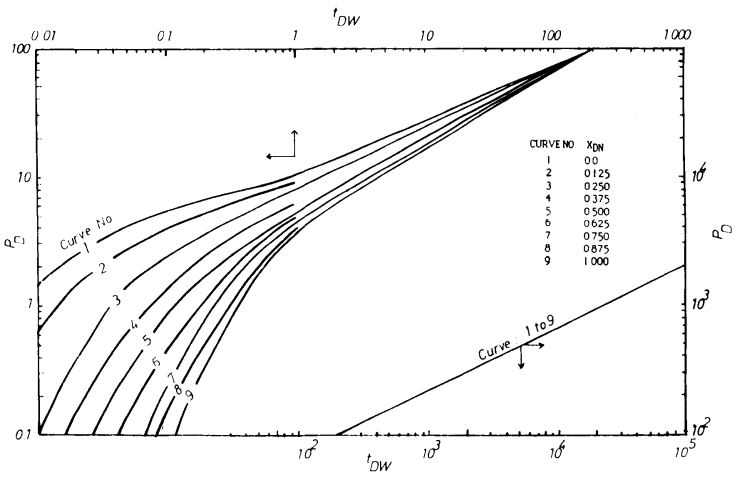

Fig. 4 Dimensionless Differential Pressure versus Dimensionless Time for Different Values of $X_{\mathrm{DN}}, X_{\mathrm{DM}}=0$ and $Y_{\mathrm{DN}}=0.125$

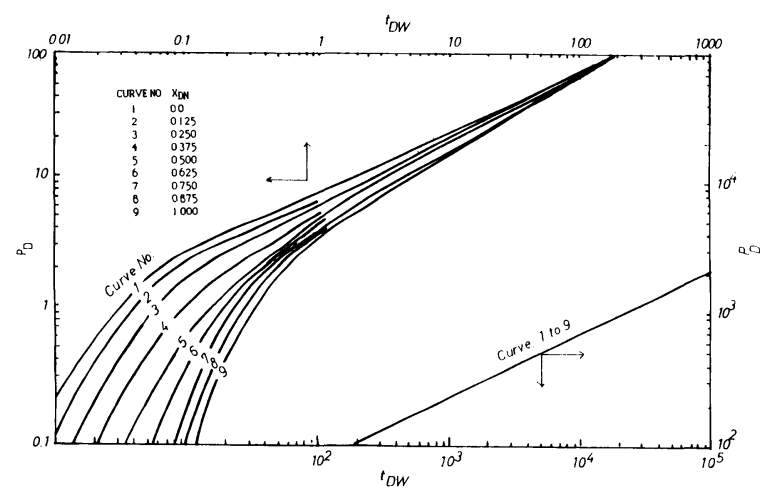

Fig. 5 Dimensionless Differential Pressure versus Dimensionless Time for Different Values of $X_{\mathrm{DN}}, X_{\mathrm{DM}}=0$ and $Y_{\mathrm{DN}}=0.25$ 


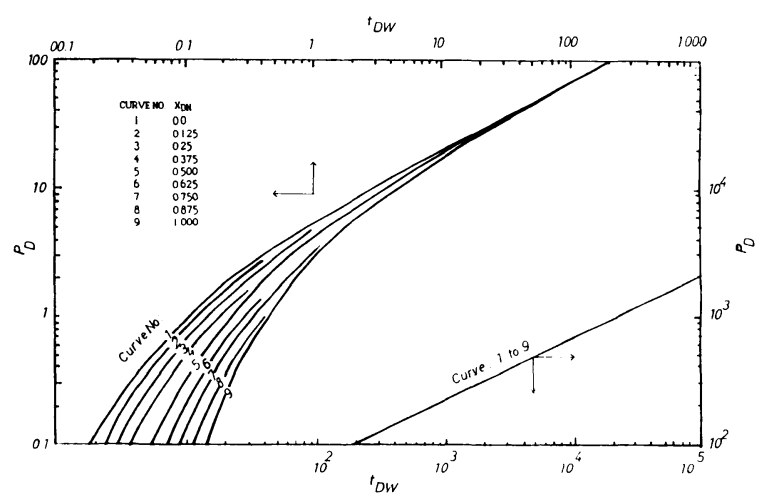

Fig. 6 Dimensionless Differential Pressure versus Dimensionless Time for Different Values of $X_{\mathrm{DN}}, X_{\mathrm{DM}}=0$ and $Y_{\mathrm{DN}}=0.5$

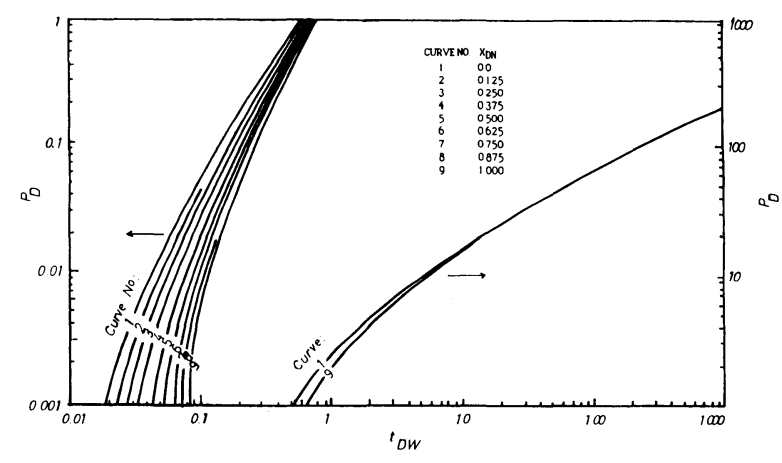

Fig. 7 Dimensionless Differential Pressure versus Dimensionless Time for Different Values of $X_{\mathrm{DN}}, X_{\mathrm{DM}}=0$ and $Y_{\mathrm{DN}}=1$

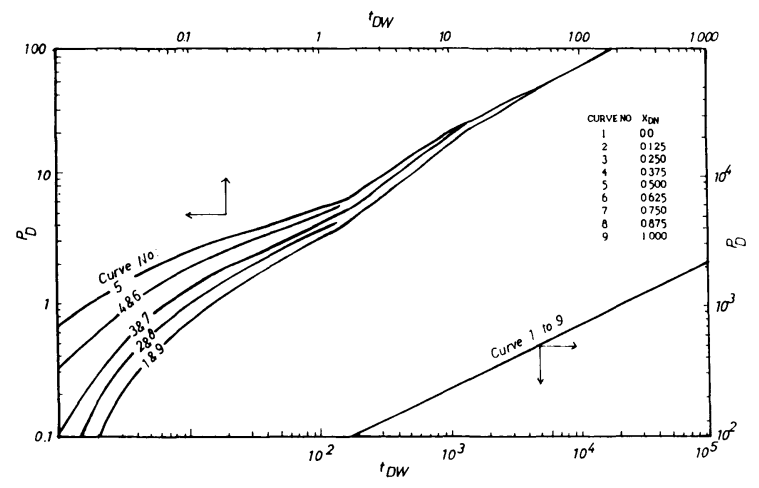

Fig. 8 Dimensionless Differential Pressure versus Dimensionless Time for Different Values of $X_{\mathrm{DN}}, X_{\mathrm{DM}}=0.5$ and $Y_{\mathrm{DN}}=0.125$

This can be understood when we keep in mind that the lst set of Figures (Figs. 4 to 7 ) presents dimensionless pressure in the later period of water injection only. On the other hand, the 2nd set of Figures (Figs. 8 to 11) presents the results for an injector located in the middle between the two faults $\left(X_{\mathrm{DM}}=0.5\right)$. Thus, the presence of the two faults has an equal effect on the dimensionless

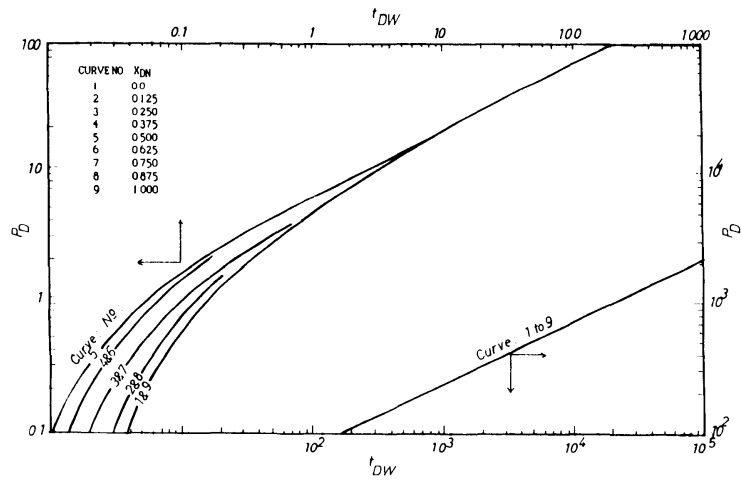

Fig. 9 Dimensionless Differential Pressure versus Dimensionless Time for Different Values of $X_{\mathrm{DN}}, X_{\mathrm{DM}}=0.5$ and $Y_{\mathrm{DN}}=0.25$

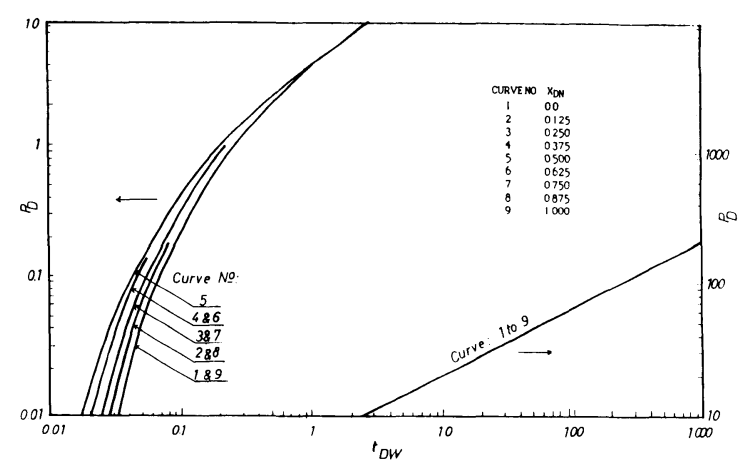

Fig. 10 Dimensionless Differential Pressure versus Dimensionless Time for Different Values of $X_{\mathrm{DN}}, X_{\mathrm{DM}}=0.5$ and $Y_{\mathrm{DN}}=0.5$

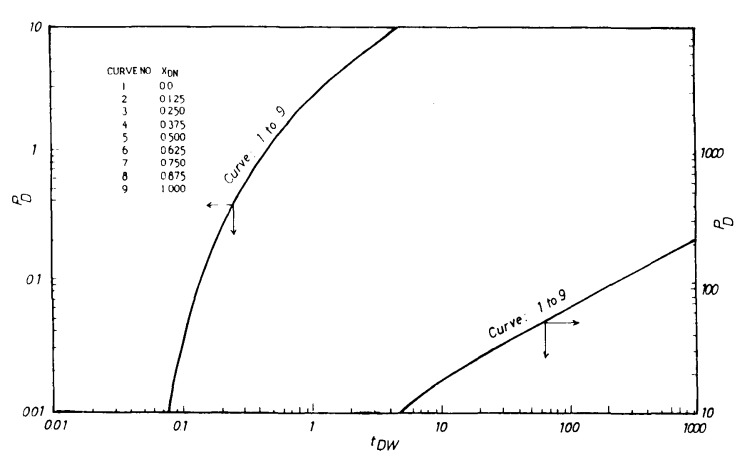

Fig. 11 Dimensionless Differential Pressure versus Dimensionless Time for Different Values of $X_{\mathrm{DN}}, X_{\mathrm{DM}}=0.5$ and $Y_{\mathrm{DN}}=1.0$

pressure. Such effect is negligible in the early period of water injection and becomes important in the later period. Figures 8 to 11 present that results for $X_{\mathrm{DN}}=0.0,0.125,0.25,0.375$ are the same for $X_{\mathrm{DN}}=1,0.875,0.75,0.625$, respectively. Such symmetry is obtained because of equality of the effect of the presence of the two faults. Figures 2 and 3 can be used to interpolate the dimensionless 
pressures for the real well and observation well coordinates which are not presented in Figs. 4 to 11.

It should be noted that only a single water injector was considered in this study. For multiwell injection system, superposition technique in space should be implemented in predicting a particular injector behaviour. It should be mentioned that the set of Eqs. (2) to (5) can be applied to any oil reservoir with three barriers, two of which are parallel and perpendicular to the third one. These barriers can be sealing faults or/ and closures.

\section{Response Time}

After a tarmat breakdown, pressure disturbance should be felt at nearby observation wells. To determine the response time at a particular observation point (well), the location of tarmat breakdown is considered as a source of water entering the reservoir at a rate equal to $f_{\mathrm{w}}$ times the injection rate $q_{w}$. The location of tarmat breakdown, the observation well and the two parallel faults can be simulated with a system of image wells similar to the system discussed earlier in the section titled "model description".

Define dimensionless gauge sensitivity as:

$$
P_{\mathrm{DS}}=-0.01417 k_{\mathrm{o}} h \alpha / \mu_{\mathrm{o}}\left(\beta_{\mathrm{w}} q_{\mathrm{w}} f_{\mathrm{w}}\right)
$$

and dimensionless response time as:

$$
\Delta t_{\mathrm{rD}}=0.0002637 k_{\mathrm{o}}\left(t_{\mathrm{r}}-t_{\mathrm{b}}\right) / \phi \mu c_{\mathrm{e}} w^{2}
$$

Then Eq. (2) is modified to calculate $P_{\mathrm{Ds}}$ as:

$$
\begin{aligned}
P_{\mathrm{DS}}= & 1 / 2\left[E i\left(-L^{2}{ }_{3 \mathrm{D}} / 4 \Delta t_{\mathrm{eD}}\right)\right. \\
& \left.+\sum_{j-1}^{\infty} E i\left(-L^{2}{ }_{4 \mathrm{D} j} / 4 \Delta t_{\mathrm{rD}}\right)\right]
\end{aligned}
$$

Thus $P_{\mathrm{D}}=2 P_{\mathrm{DS}}$ as long as the arguments of $E i$ terms are the same. Thus, the charts presented in Figs.
2 to 11 can be used to evaluate the response time at any observation well in the reservoir. It has to be kept in mind, however, that the locations of tarmat breakdown and fault No. 1 become the new reference for the observation well. In other words, the abascia $\left(X_{\mathrm{D}}\right)$ must be shifted to pass by the location of tarmat breakdown. Then, the proper chart is used to evaluate the response time. In general, Eqs. (6) to (8) can be applied to any observation well in the reservoir regardless of the location of the injector.

Eq. (6) and (8) should be solved by trial and error to calculate the response time at the observation well. Using the charts presented in Figs. 4 to 11, the calculations are straight forward for the case of constant injection rate but it could become tedious for the case of variable injection rate, as superposition in time should be implemented. In reality, the difference in time between tarmat breakdown and the response at nearest observation well $\left(t_{\mathrm{r}}-t_{\mathrm{b}}\right)$ is normally very short and thus injection during such short interval is expected to be constant.

Assuming that the tarmat would have collapsed at time $t_{\mathrm{b}}$, additional time would be required to sweep the oil between the injector and boundaries of the area of interest (the two faults, top of the reservoir and the tarmat). The injector should then be relocated to above the tarmat. The time of recompleting the well is predicted as in the previous study3).

\section{Application}

The behaviour of tarmat under water injection using an injector near two parallel faults is predicted using a set of data for the Minagish reservoir presented in Table 1. The equations and the design charts presented in this paper is used to calculate tarmat breakdown time and the response time.

The reservoir under study is the Minagish Oolite reservoir in Kuwait. The presence of tarmat in

Table 1 Average Rock and Fluid Properties

\begin{tabular}{ll}
\hline Water formation volume factor & $1.029 \mathrm{bbl} / \mathrm{STB}$ \\
Water viscosity & $0.48 \mathrm{cp}$ \\
& $@$ reservoir conditions \\
Average water saturation in the reservoir & 0.137 \\
Relative permeability to oil (at $\left.S_{\mathrm{w} i}=0.137\right)$ & 1 \\
Oil viscosity & $0.96 \mathrm{cp}$ \\
& $@ \mathrm{reservoir}$ conditions \\
Oil formation volume factor & $1.47 \mathrm{bbl} / \mathrm{STB}$ \\
Well bore radius & $0.2917 \mathrm{ft}$ \\
Relative permeability to water at residual oil saturation & 1 \\
Average reservoir effective compressibility & $1.292 \times 10^{-5} \mathrm{psi}^{-1}$ \\
Average aquifer effective compressibility & $5.6 \times 10^{-6} \mathrm{psi}^{-1}$ \\
$\sum k h$ & $172,139 \mathrm{md}^{\mathrm{ft}}$ \\
$\sum \phi h$ & $87.09 \mathrm{ft}$ \\
\hline
\end{tabular}

The data included in this table are obtained from Reference 1). 
Table 2 Data and Results of the Example

\begin{tabular}{ccccccc}
\hline $\begin{array}{c}q_{\mathrm{w}} \\
\text { [BWPD] }\end{array}$ & $\begin{array}{c}t \\
\text { [day] }\end{array}$ & $\begin{array}{c}\Delta t=t_{\mathrm{b}}-t \\
\text { [days] }\end{array}$ & $\begin{array}{c}\Delta q_{\mathrm{w}} \\
{[\mathrm{BWPD}]}\end{array}$ & $\Delta t_{\mathrm{DW}}$ & $\begin{array}{c}P_{\mathrm{D}} \\
\text { Fig. } 4\end{array}$ & $\Delta q_{\mathrm{w}} P_{\mathrm{D}}$ \\
\hline 10,000 & 0.0 & 41.0 & 10,000 & 47.7 & 52.5 & 525,000 \\
14,000 & 20.0 & 21.0 & 4,000 & 24.23 & 38.0 & 152,000 \\
16,000 & 30.0 & 11.0 & 2,000 & 12.80 & 28.0 & 56,000 \\
\hline
\end{tabular}

Minagish reservoir was indicated by samples, cores and logs. Pressure surveys that were taken in different wells indicated pressure support at different locations in the reservoir. It was not possible to history match the reservoir behaviour without considering breakdown of tarmat at certain locations in the reservoir upon pressure decline of 450 psia (3.1 MPa). The average tarmat thickness in such locations is $30 \mathrm{ft}(9.14 \mathrm{~m})$. Thus one can conclude that a differential pressure of $15 \mathrm{psi} / \mathrm{ft}(339 \mathrm{kPa} / \mathrm{m})$ across tarmat would be required to break the tarmat anywhere in the reservoir.

Assume that water is injected in a well located at one of two parallel faults which are $2,000 \mathrm{ft}$ apart. The injection rate is variable as recorded in the first two columns of Table 2. It is required to calculate the time at which the tarmat would breakdown at point $\mathrm{N}\left(1,000^{\prime}, 250^{\prime}\right)$. The tarmat thickness at point $\mathrm{N}$ is about $20 \mathrm{ft}$. Thus, differential pressure $\left(\Delta P_{\mathrm{b}}\right)$ of about 300 psi is required to break tarmat at point $\mathrm{N}$.

1) Breakdown Time

(1) Pick the proper chart as follows:

Coordinates of the injector are $(0,0)$ and those of point $\mathrm{N}$ are $X_{\mathrm{DN}}=1,000 / 2,000=0.5$ and $Y_{\mathrm{DN}}=250 / 2,000=0.125$.

Thus, Curve No. 4 of Fig. 4 is used in these calculations.

(2) Assume time of tarmat breakdown $\left(t_{\mathrm{b}}\right)$ is 41 days, then calculate $\left(\Delta t=t_{\mathrm{b}}-t\right)$ as listed in column 3 of Table 2 .

(3) Calculate $\Delta q_{\mathrm{w}}$ as listed in column 4 of Table 2.

(4) Calculate $\Delta t_{\mathrm{DW}}$ using reservoir data listed Table 1 and:

$$
\Delta t_{\mathrm{Dw}}=0.0002637 k \Delta_{\mathrm{t}} /\left(\phi \mu c_{\mathrm{t}} w^{2}\right)
$$

The results are listed in column 5 of Table 2 .

(5) Determine $P_{D}$ using Curve No. 4 of Fig. 4 (as picked in step 1) the results are listed in column 6 of Table 2.

(6) Calculate $\left(\Delta q_{\mathrm{w}} P_{\mathrm{D}}\right)$ as indicated in column 7 of Table 2 and then calculate differential pressure across tarmat using reservoir data listed in Table 1:

$$
\begin{aligned}
\Delta P & =141.2 \mu_{\mathrm{w}} \beta_{\mathrm{w}} \sum\left(P_{\mathrm{D}} \Delta q_{\mathrm{w}}\right) / k h \\
& =297 \mathrm{psi} \cong \Delta P_{\mathrm{b}}
\end{aligned}
$$

Thus $t_{\mathrm{b}}=41$ days as assumed in step 2. It should be noted that : (a) As the reservoir is stratified, $\left(\sum k h / \Sigma \phi h\right)$ is substituted in the equation of step 4 for $(k / \phi)$ and $\sum k h$ for $k h$ in the equation of step 6 .

(b) If $\Delta P$ calculated in step 6 is not equal to $\Delta P_{\mathrm{b}}$ required to break the tarmat at point $\mathrm{N}$, assume another value for $t_{\mathrm{b}}$ and repeat steps 2 to 6 till a match between $\Delta P$ calculated and $\Delta P_{\mathrm{b}}$ is obtained.

(c) For the case of variable injection rates (as in the case of this example) superposition technique in time should be applied as shown in Table 2.

(d) The pressure distribution in the reservoir (below the tarmat) can be predicted at any time of injection as done in the previous example. The trial and error steps are not needed. However, superposition technique must be implemented for variable injection rate cases.

2) Response Time

The response time is calculated using Eqs. (6) and (7) and the proper chart. The location of tarmat breakdown is regarded as source of water entering the reservoir at a rate equal to $f_{\mathrm{w}}$ times the injection rate at the time of breakdown. In the absence of reliable data of $f_{\mathrm{w}}$, an assumed value of 0.5 was used in this example. The sensitivity of the gauge used to measure the pressure at the observation well is taken as 5 psi. The time of response at a nearby well is calculated as follows:

(1) Shift the $X_{D}$ axis to the location of tarmat breakdown (point $\mathrm{N}$ in this example). Thus the coordinates of point $\mathrm{N}$ become $(0.5$, 0 ). With the new coordinates, assume that the coordinates of the observation well are $(0.875,0.125)$. Then the proper chart to be used here is curve No. 8 of Fig. 8.

(2) Calculate $P_{\mathrm{Ds}}$ using Eq. (6) and data presented in Table 1. $P_{\mathrm{DS}}=3.05$. Thus $P_{\mathrm{D}}=$ $2 P_{\mathrm{DS}}=6.1$.

(3) From the chart picked in step No. 1 (Curve 8 of Fig. 8) get $t_{\mathrm{Dw}}=2.2=\Delta t_{\mathrm{rD}}$, then use Eq. (7) to calculate the value of $\left(t_{\mathrm{r}}-t_{\mathrm{b}}\right)$. Then $t_{\mathrm{r}}$ is calculated. In this example $t_{\mathrm{r}}-t_{\mathrm{b}}=211.59 \mathrm{~h}=$ 8.8 days but $t_{\mathrm{b}}=41$ days (as calculated in Section 1 of this example). Thus $t_{\mathrm{r}}=49.8$ days.

It should be noted that the injection rate is assumed to be constant during the 8.8 davs. It was taken 
16,000 BWPD. For the variable injection rates during the period $\left(t_{\mathrm{b}}-t_{\mathrm{r}}\right)$ superposition technique should be implemented, using trial and error procedure presented in Section 1 of this example.

\section{Conclusions}

1) A set of expressions was obtained which can be generally applied to predict differential pressure across the tarmat upon injecting water by an injector located nearby two parallel faults. Also, these expressions can be applied to predict the pressure distribution anywhere in an oil reservoir with three barriers (faults and/or closures) two of which are parallel and perpendicular to the third one.

Also, response time at any observation well, and time to switch injection from below to above tarmat, were also considered.

2) Design charts were developed to predict the differential pressure across the tarmat anywhere in the reservoir, for both constant and variable injection rates. Knowing the thickness and the strength of tarmat at a particular point in the reservoir, it would be possible to predict tarmat breakage at that point at any time of water injection. For multi-well injection system, superstition technique in space should be applied for prediction of tarmat behaviour.

3) It was found that, during early period of water injection, the dimensionless pressure across the tarmat is mainly controlled by the coordinates of both the water injector and the observation point. The presence of the two parallel faults becomes the controlling factor in later period. This means that, for water injection projects which are expected to continue for long time, the selection of water injector locations between any two parallel faults becomes of minor importance.

\section{Nomenclatures}

\footnotetext{
$B_{\mathrm{w}} \quad$ : Formation volume factor of water [RB/STB (res. $\mathrm{m}^{3} /$ stock tank $\left.\mathrm{m}^{3}\right]$

$c_{\mathrm{e}} \quad$ : Total compressibility $\left[\mathrm{psi}^{-1}\left(\mathrm{kP}_{\mathrm{a}}^{-1}\right)\right]$

Ei : Exponential integral defined by:

$$
E i(-x)=-\int_{x}^{\infty} e^{-u} / u \mathrm{~d} u
$$

$f_{w} \quad$ : Fraction of injected water entering the reservoir after tarmat breakdown

$h \quad$ : Formation thickness

$k_{\mathrm{o}} \quad:$ Effective permeability to oil

$k_{\mathrm{w}} \quad$ : Effective permeability to water

[md.] $\begin{array}{ll}\text { vation well } & \mathrm{ft}(\mathrm{m})]\end{array}$

$L_{2 j} \quad$ : Distance between $j$ th image well and the observation
}

well, $(\mathrm{m})$ for the system before tarmat breakdown

$[\mathrm{ft}(\mathrm{m})]$

$L_{3} \quad$ : Distance between the location of tarmat breakdown and the observation well $[\mathrm{ft}(\mathrm{m})]$

$L_{4 j} \quad$ : Distance between the $j$ th image well and the observation well $\mathrm{ft}$ for the system after tarmat breakdown $[\mathrm{ft}(\mathrm{m})]$

$L_{1 \mathrm{D}} \quad$ : Dimensionless distance between the real well and the observation well, $L_{1} / w$

$L_{2 \mathrm{D} j} \quad$ : Dimensionless distance between the $j$ th image well and the observation point, for the system before tarmat breakdown, $L_{2 j} / w$

$L_{3 \mathrm{D}} \quad$ : Dimensionless distance between the location of tarmat breakdown and observation well

$L_{4 \mathrm{Dj}} \quad$ : Dimensionless distance between the $j$ th image well and the observation well for the system after tarmat breakdown, $L_{4 j} / w$

$P_{\mathrm{D}} \quad$ : Dimensionless pressure

$P_{\mathrm{Ds}} \quad$ : Dimensionless gauge sensitivity defined by Eq. (6)

$\Delta P \quad$ : Differential pressure at the tarmat $\quad[p s i(\mathrm{kPa})]$

$\Delta P_{\mathrm{b}}:$ Breakdown differential pressure $\quad[\mathrm{psi}(\mathrm{kPa})]$

$q_{\mathrm{w}} \quad$ : Water injection rate

$\left[\mathrm{BWPD}\left(\mathrm{m}^{3} / \mathrm{d}\right)\right]$

$\Delta q_{\mathrm{w}} \quad$ : Change in water injection rate

$S_{\mathrm{w} i} \quad$ : Average initial water saturation $\left[\mathrm{BWPD}\left(\mathrm{m}^{3} / \mathrm{d}\right)\right]$

$t \quad$ : Time

$t_{\mathrm{b}} \quad$ : Tarmat breakdown time

$t_{\text {DW }} \quad$ : Dimensionless time expressed by Eq. (3)

$t_{\mathrm{r}} \quad:$ Response time

$\Delta t \quad$ : Change in time

$\Delta t_{\mathrm{rD}} \quad$ : Dimensionless response time defined by Eq. (7)

$w \quad$ : Distance between the two parallel faults $\quad[\mathrm{ft}(\mathrm{m})]$

$X_{\mathrm{D}} \quad$ : Dimensionless distance in $x$-direction

$X_{\text {DI }} \quad$ : Abscissa of image well

$X_{\mathrm{DM}}$ : Abscissa of water injector

$X_{\mathrm{DN}} \quad$ : Abscissa of observation point

$Y_{\mathrm{D}} \quad$ : Dimensionless distance in $y$-direction

$Y_{\mathrm{DN}}:$ Ordinate of observation point

$\alpha \quad$ : Pressure gauge sensitivity

$\mu_{\mathrm{O}} \quad$ : Viscosity of oil

$\mu_{\mathrm{w}} \quad$ : Viscosity of water

$\phi \quad$ : Formation porosity

\section{References}

1) Moore, L.V, Oil \& Gas J., 109 (1984).

2) Hunt, J.M., "Petroleum Geochemistry and Geology", W.H. Freeman \& Co., San Francisco (1979).

3) Osman, M.E., JPT, 2071 (1985).

4) "Reservoir Engineering, it's role in Hydrocarbon Resources Development", Organization of Arab Petroleum Exporting Countries, Kuwait (1979), p. 11-28.

5) Bashbush, J.L. et al., "A Reservoir Optimization Study-ElBundug field, Abu Dhabi, Qatar”, paper SPE 11481 presented at the 1983 SPE Middle East Oil Technical Conference and Exhibition, Bahrain, March 14-17.

6) Shamsaldeen, S.M., Farouq Ali, S.M., “An Experimental Study of Techniques for Increasing Oil Recovery from Oil Reservoirs with Tar Barriers", Paper SPE 13705 presented at the 1985 SPE Middle East Oil Technical Conference and Exhibition, Bahrain, March 11-14.

7) Al-Kaabi, A., Menouar, H., Al-Marhoun, M., Al-Hashim, H., SPE Reservoir Engineering, 395 (1988).

8) Tripathy, B., SPE Reservoir Engineering, 1109 (1988).

9) Osman, M.E., Oil \& Gas J., 84, 55 (1986).

10) Osman, M.E., SPE Reservoir Engineering, 207 (1988). 
要 旨

互いに平行なニつの断首を伴う油首に水を圧入したときタールマットに生じる差压の予㑚

Mohammed El-Sayed Osman

Chemical \& Petroleum Eng. Dept., University of United Arab Emirates, P. O. Box 17555, Al-Ain, Abu Dhabi, U. A. E.

油層中の油と水の境界面に, タールマットと呼ばれる層状の 重質油を形成する油層が数多く存在する。このタールマットに 対し垂直で，互いに平行な二つの断層を伴う水を压入したと き, 任意の点のタールマット上下に生じる差圧について解析 し，差圧を予測する解析的手法とグラフを使用する手法を得 た。水圧入開始当初は，このタールマット上下の差圧は圧入井 と観測点の位置に大きく依存するが, 圧入が継続されるにつれ
断層の影響が強くなることがわかった。この論文に示された手 法は一般解であり，三つのバリアーをもち，その内二つが互い に平行で，かつ他の一つと垂直であるようなすべての油層に適 用可能である。また，このような条件下の任意の観測井におい て,レスポンスが得られるまでの時間を推定する式も示されて いる。

\section{Keywords}

Well test, Reservoir, Tarmat, Differential pressure, Water injection, Two parallel fault 